\title{
The Multisensory Experience of Handling and Reading Books
}

\author{
Charles Spence* \\ Department of Experimental Psychology, Anna Watts Building, University of Oxford, Oxford, \\ OX2 6GG, UK
}

Received 29 December 2019; accepted 3 April 2020

\begin{abstract}
The failure of e-books to take over from the traditional print format, as was so confidently predicted would happen only a few years ago, highlights how there is more to reading than merely the content of what we see. In fact, like any other object, the experience of interacting with a book, especially an old or historic volume, offers the reader the potential for a multisensory encounter. One that involves not only what the book looks and feels like, both the weight of the volume and the feel of the pages, but also the distinctive smell. In fact, one might also want to consider the particular sound made by the pages as they are turned over. However, it is the smell of older, and seemingly more olfactorilyredolent, works that appears to be especially effective at triggering nostalgic associations amongst readers. It is therefore only by understanding the multisensory nature of handling books, as stressed by this review, that one can really hope to fully appreciate the enduring appeal of the traditional format in the modern digital era. Several recent exhibitions that have attempted to engage their visitors by means of exploring the multisensory appeal of historic books or manuscripts in their collections are briefly discussed. While the multisensory mental imagery that is typically evoked by reading is unlikely to differ much between the print and e-book formats, there is nevertheless still some evidence to suggest that physical books can occasionally convey information more effectively than their digital counterparts.
\end{abstract}

\section{Keywords}

Books, multisensory, smell, touch, material culture, digital, weight, taste

\section{Introduction}

Given the 'sensory turn' that has been documented in so many fields of academic enquiry in recent years (e.g., Smith, 2007, 2015), it is natural to consider

\footnotetext{
${ }^{*}$ E-mail: charles.spence@psy.ox.ac.uk
} 
the multisensory attributes, not to mention appeal, of books in the same light too. Intriguingly, and contrary to so many predictions in the popular press, physical books still outsell e-books no matter whether they are read on Kindle or iPad (Preston, 2017). In 2017, for example, sales of e-books were predicted to fall by $1 \%$ whereas sales of paper books were set to rise by $6 \%$ (Bridge, 2017). According to Handley (2019): "Publishers of books in all formats made almost $\$ 26$ billion in revenue last year in the U.S., with print making up $\$ 22.6$ billion and e-books taking \$2.04 billion, according to the Association of American Publishers' annual report 2019. Those figures include trade and educational books, as well as fiction." (see Note 1). According to Nielsen Book International: "genres that do well in print include nature, cookery and children's books, while people prefer to read crime, romantic novels and thrillers via e-reader" (quote from Handley, 2019).

Interestingly, though, despite the rapid growth in portable technologies, we have also witnessed a return, especially amongst younger people, to reading on paper rather than e-books (Cain, 2017). Even more pertinent is the fact that this preference would appear to be more pronounced when people read for pleasure rather than for their business or education (see Stoltzfus, 2016). For instance, the results of a 2017 survey commissioned by eBay revealed that just over half of the more than 2000 people questioned actually preferred physical over digital versions of books, CDs and records, and boxed video games (Bridge, 2017; see also Sax, 2019).

The question here has to be why? Why exactly has the sale of e-books plateaued, and why may it even be in decline? In part, the answer may simply be that electronic books do not have anything like the same multisensory (nor nostalgic emotional) appeal as traditional books (Ruecker, 2002, 2006). At the same time, however, it is also worth highlighting the fact that $62 \%$ of the respondents in the eBay survey explicitly reported that they used physical books to help them to disconnect from the online world (Bridge, 2017). Indeed, one of the recently recognised problems with e-readers (Kindle) and tablets (iPad) is that that they can all too easily interfere with our sleep in a way that traditional books simply do not do. According to the results of a 2015 study by Chang et al., those reading an electronic book on a light-emitting device in the hours before bedtime take longer to fall asleep, feel less sleepy in the evening, secrete less melatonin, exhibit a later timing of their circadian clock, and show reduced next-morning alertness as compared to those who read a printed book instead. That said, the participants in this particular study had to read for four hours straight with the light-emitting device turned up to its maximum brightness. 


\subsection{Outline}

This review first addresses the question of why e-books have not taken over from the traditional format for reading (Section 2). One important factor identified here may be the multisensory stimulation that interacting with a print book necessarily delivers, especially an older volume, that to date has simply not been captured by their electronic counterparts (see also Ruecker, 2002, 2006). Section 3 breaks down the individual sensory inputs — sight, smell, feel, sound, and even taste - that have been shown to influence the multisensory experience of handling a physical book, especially an older volume. Thereafter, several recent attempts to organise multisensory exhibitions around the theme of books are briefly reviewed (Section 4). The review then shifts to a consideration of the multisensory nature of reading, focusing on the multisensory mental imagery, including the inner voice (or voices), that so many of us hear when we read (Section 5). Finally, Section 6 questions the claim that reading a physical book is capable of conveying information more effectively than the digital version.

\section{Why E-Books Have not Taken Over From the Traditional Physical Format}

There are likely to be a number of reasons as to why e-books have not taken over from the traditional paper format, despite the many practical benefits that the former would appear to offer (Bilton, 2012; Tedeschi, 2011). One of the first things to notice here is that e-books do not smell. As Bilton (2012) puts it: "The scent of physical books - the paper, the ink, the glue - can conjure up memories of a summer day spent reading on a beach, a fall afternoon in a coffee shop, or an overstuffed chair by a fireplace as rain patters on a windowsill. iPads and Kindles, in comparison, don't necessarily smell like anything". It would seem likely that smell would presumably come low down the list if people were asked to rank the importance of the various senses as far as their enjoyment of books are concerned (Fenko et al., 2010; see also Ruecker, 2002, 2006). Nevertheless, it turns out that olfactory cues may play an important, if unacknowledged, role in the emotional (often nostalgic) response that many of us have to handling a real book, especially an older volume. According to Strlič et al. (2009, p. 8617): "The aroma of an old book is familiar to every user of a traditional library. A combination of grassy notes with a tang of acids and a hint of vanilla over an underlying mustiness, this unmistakable smell is as much part of the book as its contents" (see also Margolies, 2006; Rindisbacher, 1992). 


\subsection{The Emotional/Nostalgic Response to Handling Books}

The handling of books, especially old and historic volumes, constitutes a genuinely multisensory experience, one that connects as much on an emotional/nostalgic as on a rational level (Borland, 2018; Griffiths and Starkey, 2018; cf. Neff, 2000). According to Meryl Halls, managing director of the Booksellers' Association in the UK, it is simply "harder to have an emotional relationship with what you're reading if it's on an e-reader" (quoted to Handley, 2019; see also Kaakinen et al., 2018 and Ruecker, 2002, 2006). Halls continues: "The book lover loves to have a record of what they've read, and it's about signaling to the rest of the world. It's about decorating your home, it's about collecting, I guess, because people are completists aren't they, they want to have that to indicate about themselves". It is, then, the long-term record of what one has read, as well as the ability to share what one has read more easily, that also helps to explain the enduring popularity of the physical book (see Anon., 2015; Note 2).

One of the key reasons as to why e-books have not caught on may, in part, also be that they simply do not provide the same emotional multisensory appeal as do their physical print counterparts. Consider here only Neff's (2000, p. 22) suggestion concerning product innovation that: “...the most successful new products appeal on both rational and emotional levels to as many senses as possible". As Bridge (2017, p. 24) notes when describing the results of the eBay survey that was mentioned earlier: "Some $70 \%$ of those surveyed said they simply liked the look and feel of physical items". In his review of manuscript-historian Christopher De Hamel's (2016) book Meetings with Remarkable Manuscripts, Thomson (2016) highlights the latter's "excitement at holding the famous Chaucer manuscript at the National Library of Wales in Aberystwyth". Notice how it is the physical object, not the story itself, that is key here.

The nostalgia associated with real books and second-hand bookshops often merits a mention online (Bilton, 2012). For instance, one commentator captured the latter associations with the physical object thus: "Print books are physical reminders of your intellectual journeys. That beat-up copy of Catcher in the Rye on your bookshelf takes you back to sophomore year of high school. The Selected Poems of Pablo Neruda conjures up memories of late-night dorm room bull sessions. The food and wine-stained Lonely Planet Greece brings back that trip through the Greek Isles. A Kindle is just a Kindle" (Anon., 2015). Though this olfactory association is likely a missed opportunity for all those modern bookstores that now smell like coffee (Luttinger \& Dicum, 2006, p. 164) or chocolate instead (Doucé et al., 2013).

Talking of nostalgic memories of books triggered by smell, my own experience as a child was with Desmond Marwood's (c. 1971), The Enchanted 


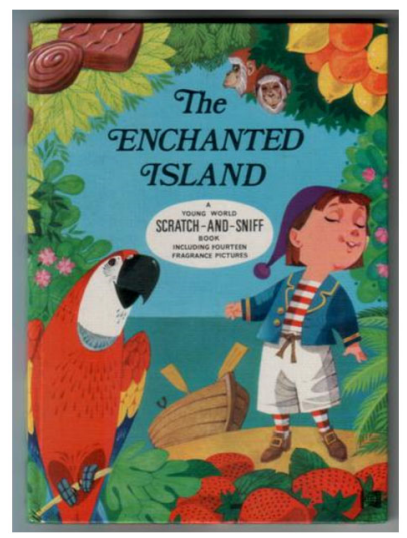

Figure 1. Front cover of Desmond Marwood's (1971), The enchanted island: A young world scratch-and-sniff book, a rare early example of a scratch-and-sniff book. This most multisensory of volumes is more memorable to your present author than any of his other less olfactorilyinteresting books from childhood. This is perhaps an example of the Proustian moment (see Chu and Downes, 2000, 2002; Herz and Schooler, 2002; van Campen, 2014).

Island: A Young World Scratch-and-Sniff Book (see Fig. 1). The multisensory experience has stayed with me for almost half a century. In fact, this volume constitutes an 'early and unusual example of a 'scratch-and-sniff' book' (https://childrensbookshop.com/book-103396.html) (Note 3). My own anecdotal experience, then, would certainly seem to agree with Laska's (2011) intuition that the distinctive smell of certain books may play an important role in aiding the recall of their contents.

\section{The Multisensory Appeal of Books}

Many scholars have acknowledged just how multisensory the experience of handling and reading a book really is. For instance, according to Baron (2015, p. 142), "Smell and sight are relevant senses when it comes to reading but touch may well be the most important". Along similar lines, Mc Laughlin (2015, p. 31) notes how "the feel of the book to the hand, the smell of the paper, the haptic pleasure of manipulating the screen [...] reinforce and deepen the habit of reading" (see also Ruecker, 2002, 2006). In the sections that follow, I want to take a closer look at the distinctive sensory features that distinguish the experience of handling physical books from their digital counterparts.

\subsection{Don't Judge a Book by Its Cover: the Visual Appearance of Books}

The cover of a book often provides the first point of contact. And crucially, the visual impression created by the cover design is likely to set expectations in the mind of the reader about the nature of the contents. Visual imagery and/or 
art works constitute a distinctive feature of many book covers too. One might therefore want to consider the sensation transference that may occur, such that what one thinks about the cover art/design is likely to carry over to influence one's expectations of the contents (Duncan and Smyth, 2019). This links to what Hagtvedt and Patrick (2008) refer to as the art infusion effect. It is, however, important to note that the impression made by a book's cover need not always be positive. Relevant in this regard, novelist Joanne Harris (author of best-selling novel Chocolat) complained recently that the 'pink and frivolous' covers that are so often used for women's novels incorporating 'frivolous cursive fonts'. She argued that this may be dissuading competition judges from taking their writing seriously (Patel, 2020; Note 4). Much like the covers of records and CDs, then, the choice of colour and typeface for a physical book may serve to communicate symbolically, on an almost emotional level, about the tone of the contents (e.g., Carroll, 2016; Childers and Jass, 2002; Fox, 2005; Haverkamp, 2014; Lupton, 2018; Morrison, 1986; Van Egmond, 2004; see also 'Register', 2020; van Rompay and Pruyn, 2011).

The typeface in which the text itself is written provides an interesting aspect of the visual appearance of every book. Consider here only how the Comic Sans typeface (created in 1994 by the Microsoft Corporation) would be wholly inappropriate for conveying anything having a serious content/theme. Another intriguing contrast here is between serif and sans serif fonts. Serifed fonts apparently look better in print, whereas sans serif looks better on the web perhaps reflecting the lower resolution of screens (cf. Garfield, 2011; Note 5). The distinctive typeface that one finds in many old books and manuscripts is also interesting in this regard (e.g., De Hamel, 2016; Thomson, 2016). While the typefaces that are used have undoubtedly changed dramatically over the centuries, then, as now, there was likely an attempt to convey meaning through the connotative meanings associated with specific typeface (see Hyndman, 2015; Velasco and Spence, 2019, for reviews). It would be interesting to study the extent to which people's experience when reading an old volume is influenced by the particular typeface in which the text is presented. The lack of processing fluency that is typically associated with reading an unfamiliar old typeface today would also be worth considering here experimentally too (cf. Celhay et al., 2015; Venkatesan et al., in press; Winkielman et al., 2003).

\subsection{Creating the Next 'Best Smeller': the Smell of Books}

Old and historic books represent a core part of our material culture (e.g., Edwards et al., 2006; see also Thomson, 2016). However, while the content of these volumes is undoubtedly key to their enduring value, it is important to note that books are fundamentally multisensory objects, and that the multisensory characteristics often tend to be more pronounced than for the case of 
contemporary volumes. For instance, many old and historic books, in particular, have a distinctive smell (Bembibre and Strlič, 2017), be it from the binding (or glue), the paper (Hunter, 1987), or perhaps even from the ink itself.

According to Cambridge University don and librarian Christopher De Hamel: "I have no vocabulary to define this, but there is a curious warm leathery smell to English parchment, unlike the sharper, cooler scent of Italian skins" (quoted in Armitstead, 2017). Meanwhile, novelist Ray Bradbury has been quoted as saying that: "If a book is new, it smells great. If a book is old, it smells even better. It smells like ancient Egypt" (Madeline Slaven, pers. comm., December 9th, 2019). According to Claire Armitstead (2017), writing in the Guardian newspaper: "Cocoa, wood, rusks - every book has a distinctive smell. And each smell says something about how and when it was made, and where it has been". Meanwhile, Alberto Manguel, director of the National Library of Argentina, says that: "he was particularly partial to old Penguin paperbacks, which he loved for their odour of 'fresh rusk biscuits" (Armitstead, 2017). Meanwhile, professor of heritage science, and trained chemist, Matija Strlič has noted that: "We know that books produced before approximately 1850 have a different smell to those produced between 1850 and 1990, and that's because late 19th-and most 20th-century printing was dominated by acid 'sizing' - the process to which pulp was subjected to reduce the water-absorbency of paper, so that it could then be written on" (quoted in Armitstead, 2017). E-books, by contrast, simply do not smell, as has already been noted (Note 6).

Anecdotally, when a book is brought to the conservators in Oxford's Bodleian Library, those working there will often comment that someone has brought in something from the Duke Humfrey's Library (https:// www.bodleian.ox.ac.uk/bodley/using-this-library/rooms/dh) based on nothing more than the smell that pervades the air when an item from this historic old reading room arrives. Once again, in this case it is unclear as to whether the smell emanates from the pages of the volumes themselves or from their bindings. Traditionally, of course, inks and dyes would have been much more olfactorily-redolent than they are today (e.g., see Blaszczyk and Spiekermann, 2017). To the knowledgeable conservator's nose, however, certain smells can also be indicative of degradation, and may signal the need to take prompt remediative action if the book or manuscript is to be saved (e.g., Adriaens et al., 2018; Strlič et al., 2009; Note 7). Recently, it was the terrible smell given by one particular volume that alerted one collector to the fact that the book in his possession had actually been covered in human skin (Wight and Dowell, 2020). Jim Drobnik (2005, p. 277) describes another instance of smell of documents being preserved. He writes: "Kate Ericson and Mel Ziegler synthesized and bottled the distinctive scent of the French National Archives in 
Paris in 1992. In this case, the odor is a mixture of decaying leather and paper, mustiness and sweat. '. . this decaying 'smell of history' is an insistent reminder of mortality and impermanence."

A wide variety of volatile organic compounds (VOCs) are emitted from paper and other cellulose-based materials during degradation (Clark et al., 2011; Lattuati-Derieux et al., 2006; Strlič and Kolar, 2008), and their build-up in libraries and other book repositories can be measured (Fenech et al., 2010). The VOCs that are often detected, especially from older volumes, include organic acids such as acetic and formic acid, as well as aldehydes, including acetaldehyde and formaldehyde (Strlič et al., 2009). Furfural has been linked to the degradation of cellulose, and benzaldehyde and vanillin to the degradation of lignin (Bembibre and Strlič, 2017).

While on the topic of the smell of print books, one might also want to consider the scented inserts that used to be such a distinctive feature of many magazines and supplements a few decades ago (see Spence, 2002, for a review). For instance, in 2007, The Los Angeles Times ran a 'scratch-and-sniff' advertisement in a 32-page section about the season's forthcoming films. According to The New York Times, "The ad, for a family movie called 'Mr. Magorium's Wonder Emporium, 'used scented ink meant to evoke the olfactory pleasures of frosted cake"'. (Elliott, 2007). The suggestion in this case was that print publishers were looking for new ways to use fragrance in order to entice marketers to spend more. This was particularly important given the increasing loss of ad revenue to online media. Interestingly, though, in this case, in order to avoid complaints around unwanted exposure to fragrance, those paying for the ad wanted to ensure that 'you have to do something to the ad to make it smell' (Elliott, 2007). Going much further back, one finds Aikman (1951, pp. 545-546) writing about periodicals being printed on scented paper, with the article's author at one point, describing experiments to 'spice' a cookbook, hinting' at unexplored possibilities for best smellers'.

\subsection{Handling: the Feel of Books}

One of the most impressive aspects of many books, especially older volumes and manuscripts, is their heft and weight. Weight in the hand, as when we hold something heavy, is typically taken to denote quality and expense (e.g., Ackerman et al., 2010; Jostmann et al., 2009; Spence, 2019a; Spence and Piqueras-Fiszman, 2011). There is, after all, more than a grain of truth to the phrase 'A weighty matter', and as Linden (2015a, p. 15) observes of people interacting with books in the store: "once a book is selected, there is usually a brief moment of assessing its weight. Again, this is not always a conscious process". Ackerman et al. (2010) published the results of a fascinating study in Science in which job applicants were shown to be rated more highly when their curriculum vitae has a heavy rather than light cover (even if the CV itself 
remained unchanged). That is, certain tactile attributes of objects, even when not directly relevant to a given judgement, can nevertheless still affect people's perception and behaviour. At the same time, however, there would also appear to be a link between micro-books and devotional experience (Send, 2018), perhaps because at times of persecution such works can more easily be hidden and/or kept close to the body.

It is easy to imagine how the thickness of the paper may also cue quality, though I am not aware of anyone having studied this. The important role that touch has been argued to play in connoisseurship is perhaps also worth stressing here (MacDonald, 2007). The importance of handling to our understanding of material culture is undoubtedly a topic of growing academic interest (e.g., see Bacci and Pavani, 2014; Chatterjee, 2008; Pye, 2007). For instance, many of the respondents in a questionnaire study reported by Ruecker $(2002,2006)$ also drew attention to how much they liked the feel and weight of real books, and how the quality of the haptic interaction changed as a book was repeatedly read or browsed through. Meanwhile, a recent article by Hernandez (in press) also stresses the importance of the feel of the weight of physical books. There is, then, a proprioceptive/kinaesthetic component to reading (McLaughlin, 2015).

One relevant notion here is that of affective ventriloquism, namely that what people think about a product, in this case the contents of a book, is likely influenced by what they think, or feel, about the packaging, in this case the cover of the book (see Spence and Gallace, 2011). Indeed, the subtle tactile cues have been shown to influence our purchasing decisions of even high-value products, such as the feel of the pocket lining when purchasing a fur coat (see Sheldon and Arens, 1932; and see Spence, 2019b, for a recent review).

The feel of the pages and their consistency throughout a volume also constitute salient sensory characteristics. For instance, the deliberate use of variation to contrast different textures is also an intriguing aspect of the feel and/or look of the pages of a physical volume (Kuitert, 2015). The contrast between different materials can, on occasion, be found in historic books (including a number of the volumes in the special collection of the Bodleian Library in Oxford). However, a similar approach is occasionally encountered in some contemporary volumes too. For instance, The Aviary Cocktail Book (Achatz et al., 2018) provides one such example, where the change in material is used to distinguish between the two main sections of the book. At this point, it is worth highlighting the fact that some differences in surface feel that are distinguishable by touch may not necessarily be visible to the naked eye (Skedung et al., 2013).

A recent trade publication was designed/launched specifically to draw attention to the joy of the physical in a digital age (Sappi Europe and Brown, 2019). Indeed, many books, very often those dealing with design or tactility 
have covers that have been treated in such a way as to give an unusual/distinctive feel. Lupton's (2007) Skin: Surface, Substance, and Design has a distinctive aerated smooth plastic cover. The unusually-textured finish is also a distinctive feature of Lupton and Lipps' (2018), The Senses: Design beyond Vision and of Hartmann and Haupt's (2016), Touch! Der Haptic-Effekt im multisensorischen Marketing [Touch! The haptic effect in multisensory marketing]. North American neuroscientist David Linden also chose to draw attention to the tactility of his book Touch: The Science of Hand, Heart, and Mind (Linden, 2015a, b). His book is covered in a thermally-responsive material in an attempt to entice more people to interact with it in the bookstore. This is likely to be a sensible idea as the likelihood of someone purchasing a product increases dramatically if they can be encouraged to pick it up in the store (see Spence, 2019b, for a review). The distinctive haptic experience associated with the handling of such volumes is obviously lost as soon as one switches to the e-book format.

At the same time that a customer's tactile interaction with a product increases the likelihood of purchase, it can also lead to worries about tactile contamination (see Argo et al., 2006; Linden, 2015a). This dislike of items that others have already touched presumably helping to explain why so many of us take a newspaper from somewhere other than the top of the pile! However, at the opposite extreme, items can also take on a special value if they happen to have been touched, used, or read by some figure of particular historic merit/relevance (see Gallace and Spence, 2014; Parisi, 2018; Thomson, 2016). For instance, take T. E. Lawrence's copy of the novel Ulysses, which has 'a sweet, somewhat smoky aroma that suffuses every bit of paper and leather' (Oram and Bishop, 2005). According to the latter commentators, researchers were sufficiently intrigued to find out more about the author's life experiences that may have underpinned the fragrant notes associated with the book (see also Bembibre and Strlič, 2017). Note again how this 'relic'-like response is lost when reading via a digital device. A little closer to home, one might think about handling books that meant something to now-deceased family members.

\subsection{The Sound and Feel of Interacting With Books}

The sound and feel of paper as the reader touches the pages, and the sound made by the latter as they are being turned over by the reader (e.g., Guest et $a l ., 2002)$, also constitute part of the multisensory experience when reading a physical book. As one commentator put it: "Print books have pages that are nice and soft to the touch. Paper makes reading physically pleasurable. Reading an e-book, on the other hand, feels like using an ATM. And after staring at a computer screen at work all day, how relaxing is it to curl up at home and stare at another screen?" (Anon., 2015). Meanwhile, in his essay on aesthetics, Japanese writer Junichirō Tanizaki (2001, pp. 17-18) notes that 
"Western paper turns away the light, while our paper seems to take it in, to envelop it gently, like the soft surface of a first snowfall. It gives off no sound when it is crumpled or folded, it is quiet and pliant to the touch as the leaf of a tree."

Some of the respondents in Ruecker's study $(2002,2006)$ did mention that they appreciated the crispness of the pages in a new book, others that they enjoyed the feel of the paper itself. That said, to the best of my knowledge there has not, as yet, been much research on the sound made by books as the pages are turned (see Stanton and Spence, 2020, for a recent review of audiotactile interactions in the context of action). In passing, consider only how some ereaders attempt to imitate the sound using an auditory page-turning icon (see Gaver, 1986).

And beyond the sound of the books themselves as they are interacted with, there is also the unique soundscape of the places in which those books are stored and read. In order to help people cope with pandemic lockdown, the Bodleian Library in Oxford recently released a stream of the sounds of the university, such creaks, rustles, coughs and traffic noises that you would normally hear in the libraries and the Radcliffe Camera; they even have a recording from the Duke Humfrey's library (see the Sounds of the Bodleian website; https://www.ox.ac.uk/soundsofthebodleian/\#radcam; Kidd, 2020).

\subsection{The Taste of Books}

Taste (or gustation) is not a sense that one normally associates with handling books. In a historical context, though, it can be imagined how readers would once have licked/moistened their fingers in order to make it easier to turn the pages of a substantial volume (Note 8). This would have meant that they, in some sense at least, tasted, albeit indirectly, the books that they were examining. Indeed, a number of the historic illustrated manuscripts in the collection at the Bodleian Library in Oxford show evidence of former readers' saliva smudging certain of the images. One might also want to mention here Francis Bacon's (1601) very old adage that "Some books are to be tasted, others to be swallowed, and some few to be chewed and digested". On one documented occasion, such advice was taken literally: the guests at one party were instructed to chew pages from Clement Greenberg's Art in London, where John Latham was teaching at the time (John Latham with Barry Flanagan, Still and Chew, 1966-67; see also Stiles, 1998). This example is recounted together with the following quote in Kirshenblatt-Gimblett (1999, p. 9). "Examples abound of edible texts, from alphabet soup and birthday cakes to Ro Malone's cooked books" (Note 9). 


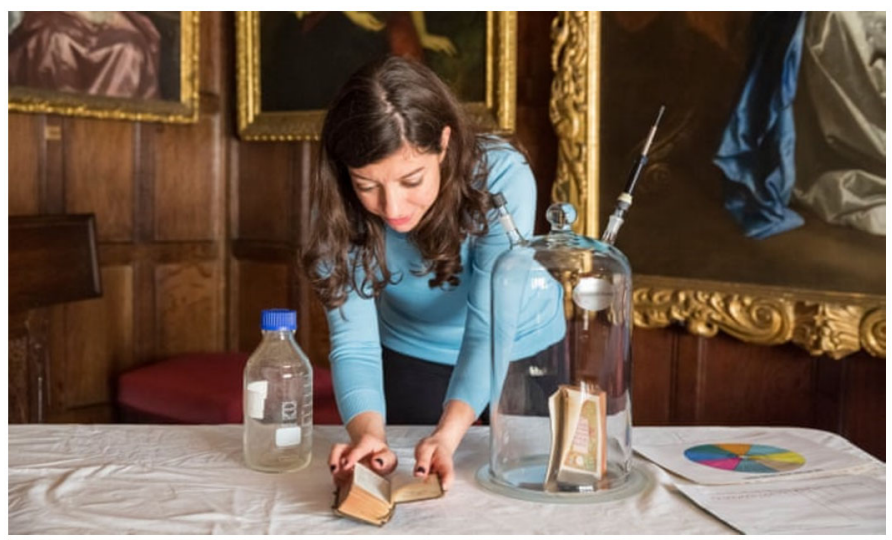

Figure 2. Researcher Cecilia Bembibre extracts the smell of an 18th-century Bible, to be logged using her 'odour wheel', shown to the right of the picture on the table. (Photograph: National Trust/James Dobson).

\section{The Multisensory Display of Books}

The growing recognition of the importance of the multisensory, and specifically the non-visual, attributes of old books has led a number of museums, libraries, and archives to put on exhibitions that try to engage more of the visitor's senses (e.g., Bacci and Pavani, 2014; Classen, 2017; Classen and Howes, 2006; Levent and Pascual-Leone, 2014). Over the last few years, events have been organised at St. Paul's Cathedral Library (Bembibre and Strlič, 2017), the Birmingham Museum and Art Gallery, and, in late 2020, the Sensational Books exhibition at the Weston Library, part of Oxford's Bodleian Library (https://visit.bodleian.ox.ac.uk/events-exhibitions; see also De Bruxelles, 2020).

Bembibre and Strlič (2017) analysed samples from an old book picked up in a second-hand shop (see Fig. 2). This enabled the researchers to develop a 'historic book odour wheel'. And, as for many other odour/flavour wheels, the idea here is that this helps connect identifiable chemicals with people's reactions to them. Thereafter, using fibres from the novel, an "extract of historic book" was produced, and presented to 79 visitors to Birmingham Museum and Art Gallery. The words that were most frequently used to describe the smell of a copy of Romanian writer Panait Istrati's 1928 novel Les Chardons du Baragan were 'chocolate'/'cocoa'/'chocolatey' followed by 'coffee', 'old', 'wood' and 'burnt'. "'From the analytical perspective, and given that coffee and chocolate come from fermented/roasted natural lignin and cellulose-containing product, they share many VOCs (volatile organic compounds) with decaying paper,' wrote the researchers" (quoted in Armitstead, 2017). 
Intriguingly, it is the smell of old books that one individual who had lost his sense of smell recounts as being a key scent that highlighted his loss (Classen et al., 1994).

The undoubted interest and olfactory appeal of old books and manuscripts also fits in with a more general fascination with historic scents and smells (e.g., Bembibre and Strlič, 2017; Blackson, 2008; Greenwood, 2017; Jenner, 2011; Jones, 2010; Reinarz, 2014). At the same time, however, it is important to note that there are practical curatorial challenges around the use of scents in heritage spaces (see Drobnick, 2006, 2014; Henshaw et al., 2018). At this point, one might also ask how exactly those exhibitions and displays that have attempted to bring old and historic book to life have achieved their goals. While in some cases the multisensory angle relates specifically to the handling of the books themselves, on other occasions the aim may rather be to illustrate some aspect of the book's contents by means of enhanced multisensory engagement. Think here, for instance, how a curator might attempt to recreate the sights, sounds, and smells associated with the Canterbury Tales without it necessarily relating to the book itself (see also Aggleton and Waskett, 1999, on the use of smell in a museum setting). The Sensational Books exhibit to be held later in the year at the Weston Library in Oxford promises to capture, and synthetically reproduce, the scent of the historic Magna Carta. There is, of course, also an accessibility opportunity by extending museum book displays beyond the merely visual gaze (Graven et al., 2020).

\section{Multisensory Mental Imagery Evoked by Reading}

While the multisensory aspects of handling books mainly has to do with perception, the multisensory aspects of reading are concerned mostly with the rich mental imagery that is evoked by the written word. The multiple sensory aspects of mental imagery that may be at work during reading include the auditory 'inner voice' during silent reading (e.g., Moore and Schwitzgebel, 2018; Perrone-Bertolotti et al., 2012), and the complementary 'inner ear' imagining any non-speech sounds that may be evoked in a passage (e.g., Brunyé et al., 2010). There is even some evidence that readers may give different characters given different voices too (Alexander and Nygaard, 2008; Kurby et al., 2009). For many people, visual imagery is also elicited while reading (e.g., Boerma et al., 2016; Brosch, 2018).

Mental imagery may also be triggered in other sensory modalities while reading. For instance, olfactory and somatosensory mental imagery likely also occur, in at least some individuals. Indeed, reading olfactory descriptors, or words related to a distinctive smell, such as the word 'cinnamon', has been shown to give rise to increased activation in olfactory brain areas (González 
et al., 2006). Potentially relevant here, there has been something of a 'sensory turn' in literature in recent years. What this means, in practice, is that a number of novelists have started to increase the amount of sensory descriptive language in their works (see also Alryyes, 2006; Harris, 1997; Hertel, 2016; Vinge, 1975).

Australian novelist Tim Winton is one author whose work has been identified as being especially sensory in terms of the language used. According to one review of Winton's novel Breath (Winton, 2008), the author was quoted as saying that he wanted: "to give people an experience, taking the reader from their world and to achieve sensory momentum" (Eshelby, 2008, p. 69). Hence, when thinking of the olfactory imagery demonstrated by the laboratory research that was mentioned a moment ago, one can perhaps imagine how active the reader's olfactory cortex must be when reading the following sentences from the novel: "She was a foot away. She smelled of butter and cucumber and coffee and antiseptic."

Ultimately, there would not seem to be much difference between physical and digital in their capacity to evoke mental imagery. However, this remains an empirical question that has yet to be addressed formally. What is more, it is currently unclear whether the enhancements (speaking characters, animations, etc.) that have been incorporated into some of the latest digital books might one day serve to replace the need (or opportunity) to engage the reader's mental imagery capacities so fully. Another intriguing, though as yet unanswered, question here concerns how any such reduction in evoked mental imagery affects comprehension/learning outcomes, enjoyment, engagement etc. Such questions, though, start to take us away from the key themes of this review, namely the multisensory experience of handling and reading books.

\section{Do Physical Books Really Convey Information Better Than the Digital Version?}

As one commentator noted: "You can write in the margins of a print book, dog-ear the important pages, and underline the key sentences with a pencil. Ebooks often allow the digital equivalents of these acts - but they just aren't the same. There is a link between physical gestures and cognition: the things we do to print books seem to help us to understand and remember better" (Anon., 2015). Indeed, longhand note taking has been shown to have advantages over laptop note taking (Mueller and Oppenheimer, 2014), perhaps connected to the superiority of multisensory to unisensory encoding of memory (cf. O'Connor, 1969). The reader's sense of immersion, or engagement, may also differ between physical and digital formats (Mangen and Kuiken, 2014). One has more of a sense how far one has progressed through a physical book, or as Anne Mangen puts it: "When you read on paper you can sense with your fingers 
a pile of pages on the left growing, and shrinking on the right. You have the tactile sense of progress, in addition to the visual... [The differences for Kindle readers] might have something to do with the fact that the fixity of a text on paper, and this very gradual unfolding of paper as you progress through a story, is some kind of sensory offload, supporting the visual sense of progress when you're reading. Perhaps this somehow aids the reader, providing more fixity and solidity to the reader's sense of unfolding and progress of the text, and hence the story" (as quoted in Flood, 2014).

Print books might also be more effective at conveying information to the reader. This, at least, was the claim made in a study by Mangen et al. (2019) that was first reported in the Guardian newspaper in 2014 (see Flood, 2014). Mangen and colleagues apparently found that those readers using a Kindle were less likely to recall events in a mystery novel, a 28-page short story of 10800 words by Elizabeth George, than those who read the same novel in print format. The sample size in this particular study was, though, quite small ( $n=25$ in each group, and only two were experienced Kindle users). Nevertheless, similar claims concerning format effects on the reading experience and/or on the recollection of what has been read have also been made by a number of other researchers over the years (e.g., see Ackerman and Goldsmith, 2011; Delgado et al., 2018; Dell'Antonia, 2011; Grothaus, 2019; Halamis and Elbaz, 2019; Hou et al., 2017; Mangen et al., 2013; Parish-Morris et al., 2013; Roseberry et al., 2009; Singer and Alexander, 2017; Troseth et al., 2020; Wolf, 2018; Woody et al., 2010; though see also Köpper, Mayr and Buchner, 2016). Although there is not space to discuss these studies in detail here, in general, there would appear to be some agreement for a modest, albeit nuanced, influence of reading format on various outcome measures (see also Walsh, 2016, for a review).

There is undoubtedly also an important accessibility aspect to the question of book format too. For many years, a number of famous authors have resisted the move to e-books. For instance, J. D. Salinger famously refused to release digital versions of his books, as did Maurice Sendak and Ray Bradbury. According to recent reports, though, the late author's estate have now decided to make J. D. Salinger's books available in e-book format (Cain, 2019). In this case the reason was of improving accessibility for those suffering from a visual impairment. Audiobooks should probably also be mentioned here (cf. Graven et al., 2020). In relation to the latter case, though, Rogowsky et al. (2016) reported that comprehension in those who just read a couple of chapters of a novel, just listened to it, or read the e-text while listening to the digital audiobook audio show no differences in comprehension when tested immediately after reading, nor when tested again two weeks later (see also Heid, 2018).

Finally here, it is interesting to take a historical perspective on reading and technology for a moment. Hernandez (in press) has recently drawn attention to 


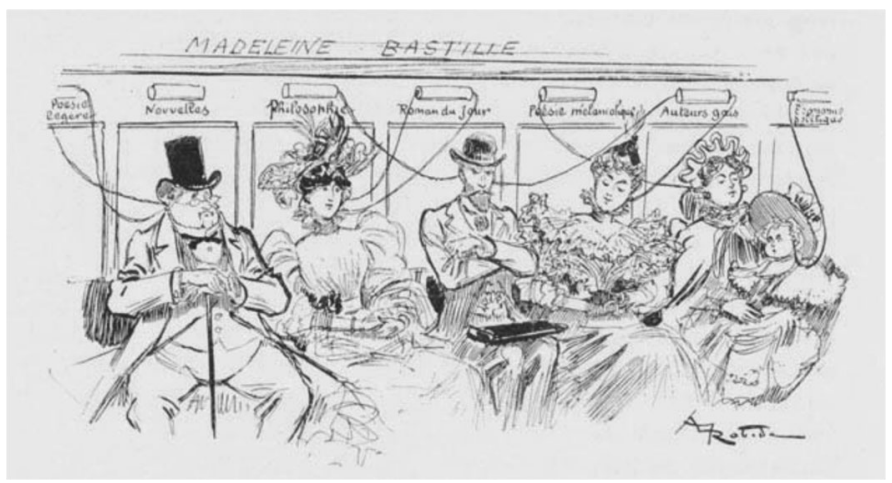

Figure 3. Listening instead of reading. Prediction by Albert Robida and Octave Uzanne (Uzanne, 1895), reprinted in Hernandez (in press).

a couple of intriguing examples showing how people at the end of the 19th century were worried that people would listen to books rather than read (Uzanne, 1895). However, once again this predicted change to our reading behaviour (see Fig. 3) never took off.

\section{Conclusions}

Reading a physical book is a much more multisensory experience than reading the same content digitally. First-person reports clearly highlight the emotional, and very often nostalgic, associations that are triggered by the smell of, especially older, books. The feel and sound of interacting with (i.e., handling) a physical book is also very different from the digital version of the same experience (Ruecker, 2002, 2006). The limited success of e-readers can therefore presumably be explained, at least in part, by their failure to acknowledge the importance of the non-visual senses to the reader's experience. Indeed, the evidence outlined here might be taken to suggest that digital innovation has not, so far, been able to successfully reproduce or substitute for the pleasures that are associated with tactile and haptic contact with the objects that we use on an everyday basis (and perhaps, as Jacques Derrida (2005) notes in his book Paper Machine, the "e-book, is just a phase in the evolution of reading technologies"; see also Hernandez, in press). Recognizing the importance of multisensory stimulation, a number of recent exhibitions have started to foreground how the experience of interaction with old books can stimulate all of the senses. At the same time, however, when it comes to the multisensory imagery that is triggered while reading, there is far less evidence thus far for a convincing difference between formats. Differences in comprehension and memorability between formats, digital, audiobook, and traditional printed format also appear to be fairly modest. 


\section{Notes}

1. Though given the substantial price differential between print and e-books, actual sales figures would presumably be more informative than the financial figures reported here.

2. Another, less prosaic, reason for the revival of the physical book may be to do with the rise of the 'shelfie' (see Bridge, 2017). According to newspaper reports, it would appear that these days twentysomethings increasingly want to share 'shelfies' - that is, pictures of shelves of physical books, vinyl records, DVDs, etc. on sites such as Instagram.

3. The good news, as I discovered recently, is that the odours are non-toxic too (see Alderson, 1973).

4. According to Harris: "Books are subconsciously perceived to be more literary, and therefore of more value, if they have male-coded packaging. That means neutral imagery; male figures; a 'serious' font" (quoted in Patel, 2020).

5. It would be interesting to know whether printed and e-book versions of the same text use different fonts, though I have not been able to find any information on this particular score (though see https://designshack.net/articles/ typography/serif-vs-sans-serif-fonts-is-one-really-better-than-the-other/).

6. Though presumably it cannot be too long before someone spots a gap in the market and comes along with a plug-in old book scent to match the new car smell that exerts such a profound influence over people's perception of their own car (e.g., Hamilton, 1966; Moran, 2000a, b, c; Van Lente and Herman, 2001; see also Braun et al., 2016). The British Library shop sells a candle that is supposed to smell of 'library' (Armitstead, 2017; see also Bembibre and Strlič, 2017; Kuitert, 2015).

7. Another scent that signals danger is the recently-developed 'smell of data', which is designed to be released by a plug-in scent-dispenser when one's digital technology is in danger of being compromised over the internet (see Jones, 2017; https://smellofdata.com/; and see Whitelocks, 2012, for an attempt to synthetically recreate the distinctive smell of a computer).

8. This scene was captured in the movie version of Umberto Eco's (1983) The Name of the Rose. Until recently, one would also see bank tellers wetting their fingers before counting a stack of bank notes. Something that is no doubt going to become an even more distant memory in the era of COVID-19, and the weaponisation of saliva and other bodily fluids. 
9. The scratch-and-sniff aromas in The Enchanted Island (Marwood, 1971), mentioned earlier, were all associated with edible products such as citrus, chocolate, strawberries, and peppermint sweets. Thus, it can be said that olfactory cues were being used to evoke specific tastes, or better said, flavours.

\section{References}

Achatz, G., Kokonas, N., Hemberger, A., Hemberger, S. and Melton, M. (2018). The Aviary Cocktail Book. The Alinea Group, Chicago, IL, USA.

Ackerman, J. M., Nocera, C. C. and Bargh, J. A. (2010). Incidental haptic sensations influence social judgments and decisions, Science 328, 1712-1715. DOI:10.1126/science.1189993.

Ackerman, R. and Goldsmith, M. (2011). Metacognitive regulation of text learning: on screen versus on paper, J. Exp. Psychol. Appl. 17, 18-32. DOI:10.1037/a0022086.

Adriaens, M., Bioletti, S. and Rabin, I. (Eds) (2018). Chemical Interactions Between Cultural Artefacts and Indoor Environment. Uitgeverij Acco, Leuven, Belgium.

Aggleton, J. P. and Waskett, L. (1999). The ability of odours to serve as state-dependent cues for real-world memories: can viking smells aid the recall of viking experiences?, Br. J. Psychol. 90, 1-7. DOI:10.1348/000712699161170.

Aikman, L. (1951). Perfume, the business of illusion, Natl Geogr. 99, 531-550.

Alderson, B. (1973). Looking at Picture Books. Bocardo Press, Oxford, UK.

Alexander, J. D. and Nygaard, L. C. (2008). Reading voices and hearing text: talker-specific auditory imagery in reading, J. Exp. Psychol. Hum. Percept. 34, 446-459. DOI:10.1037/ 0096-1523.34.2.446.

Alryyes, A. (2006). Description, the novel and the senses, Sens. Soc. 1, 53-70. DOI:10.2752/ 174589206778055583.

Anon. (2015). Drop that Kindle! 10 reasons print books are better than e-books. Huffington Post. Available at: https://www.huffpost.com/entry/drop-that-kindle-10-reaso_b_8234890.

Argo, J. J., Dahl, D. W. and Morales, A. C. (2006). Consumer contamination: how consumers react to products touched by others, J. Mark. 70, 81-94. DOI:10.1509/jmkg.70.2.081.

Armitstead, C. (2017). Can you judge a book by its odour? Guardian, April 7th. Available at: https://www.theguardian.com/books/2017/apr/07/the-smell-of-old-books-science-libraries.

Bacci, F. and Pavani, F. (2014). First hand, not 'first eye' knowledge: bodily experience in museums, in: The Multisensory Museum: Cross-Disciplinary Perspectives on Touch, Sound, Smell, Memory, and Space, N. Levent and A. Pascual-Leone (Eds), pp. 17-28. Rowman \& Littlefield, Lanham, MD, USA.

Bacon, F. (1601). Of studies, in: Essays. F. Bacon (Ed.). Available at: https://www.vonsteuben. org/ourpages/humanities/bacon.pdf.

Baron, N. S. (2015). Words Onscreen: the Fate of Reading in a Digital World. Oxford University Press, Oxford, UK.

Bembibre, C. and Strlič, M. (2017). Smell of heritage: a framework for the identification, analysis and archival of historic odours, Herit. Sci. 5, 2. DOI:10.1186/s40494-016-0114-1.

Bilton, N. (2012). An e-book fan, missing the smell of paper and glue, N. Y. Times, June 18th. Available at: https://twosidesna.org/US/an-e-book-fan-missing-the-smell-of-paperand-glue/. 
Blackson, R. (2008). If There Ever Was: a Book of Extinct and Impossible Smells. Cornerhouse, Manchester, UK.

Blaszczyk, R. L. and Spiekermann, U. (Eds) (2017). Bright Modernity: Color, Commerce, and Consumer Culture. Palgrave Macmillan, Cham, Switzerland.

Boerma, I. E., Mol, S. E. and Jolles, J. (2016). Reading pictures for story comprehension requires mental imagery skills, Front. Psychol. 7, 1630. DOI:10.3389/fpsyg.2016.01630.

Borland, J. (2018). Moved by medicine: the multisensory experience of handling folding almanacs, in: Sensory Reflections: Traces of Experience in Medieval Artifacts, F. Griffiths and K. Starkey (Eds), pp. 203-224. Walter de Gruyter, Berlin, Germany. DOI:10.1515/ 9783110563443-010.

Braun, M. H., Pradana, G. A., Buchanan, G., Cheok, A. D., Velasco, C., Spence, C., Aduriz, A. L., Gross, J. and Lasa, D. (2016). Emotional priming of digital images through mobile telesmell and virtual food, Int. J. Food Des. 1, 29-45. DOI:10.1386/ijfd.1.1.29_1.

Bridge, M. (2017). Shelf-conscious millennials give books and vinyl a boost, Times, November 14th. Available at: https://www.thetimes.co.uk/article/shelf-conscious-millennials-givebooks-a-boost-rmcnnsvnl.

Brosch, R. (2018). What we 'see' when we read: visualization and vividness in reading fictional narratives, Cortex 105, 135-143. DOI:10.1016/j.cortex.2017.08.020.

Brunyé, T. T., Ditman, T., Mahoney, C. R., Walters, E. K. and Taylor, H. A. (2010). You heard it here first: readers mentally simulate described sounds, Acta Psychol. 135, 209-215.

Cain, S. (2017). Ebook sales continue to fall as younger generations drive appetite for print, Guardian, March 14th. Available at: https://www.theguardian.com/books/ 2017/mar/14/ebook-sales-continue-to-fall-nielsen-survey-uk-book-sales.

Cain, S. (2019). JD Salinger estate finally agrees to ebook editions, Guardian, August 12th. Available at: https://www.theguardian.com/books/2019/aug/12/jd-salinger-estatefinally-agrees-to-ebook-editions.

Caroll, J. (2016). The art of the sleeve: every album cover tells a story, Ir. Times, October 13th. Available at: https://www.irishtimes.com/culture/music/the-art-of-the-sleeve-every-albumcover-tells-a-story-1.2821084.

Celhay, F., Boysselle, J. and Cohen, J. (2015). Food packages and communication through typeface design: the exoticism of exotypes, Food Qual. Pref. 39, 167-175. DOI:10.1016/ j.foodqual.2014.07.009.

Chang, A.-M., Aeschbach, D., Duffy, J. F. and Czeisler, C. A. (2015). Evening use of lightemitting eReaders negatively affects sleep, circadian timing, and next-morning alertness, Proc. Natl Acad. Sci. USA 112, 1232-1237. DOI:10.1073/pnas.1418490112.

Chatterjee, H. J. (2008). Touch in Museums: Policy and Practice in Object Handling. Berg Publishers, Oxford, UK.

Childers, T. L. and Jass, J. (2002). All dressed up with something to say: effects of typeface semantic associations on brand perceptions and consumer memory, J. Consum. Psychol. 12, 93-106. DOI:10.1207/S15327663JCP1202_03.

Chu, S. and Downes, J. J. (2000). Odour-evoked autobiographical memories: psychological investigations of Proustian phenomena, Chem. Senses 25, 111-116. DOI:10.1093/chemse/ 25.1.111.

Chu, S. and Downes, J. J. (2002). Proust nose best: odors are better cues of autobiographical memory, Mem. Cogn. 30, 511-518. DOI:10.3758/BF03194952. 
Clark, A. J., Calvillo, J. L., Roosa, M. S., Green, D. B. and Ganske, J. A. (2011). Degradation product emission from historic and modern books by headspace SPME/GC-MS: evaluation of lipid oxidation and cellulose hydrolysis, Anal. Bioanal. Chem. 399, 3589-3600. DOI:10. 1007/s00216-011-4680-5.

Classen, C. (2017). The Museum of the Senses: Experiencing Art and Collections. Bloomsbury, London, UK.

Classen, C. and Howes, D. (2006). The museum as sensescape: western sensibilities and indigenous artefacts, in: Sensible Objects: Colonialism, Museums and Material Culture, E. Edwards, C. Gosden and R. B. Phillips (Eds), pp. 199-222. Berg, Oxford, UK.

Classen, C., Howes, D. and Synnott, A. (1994). Aroma: the Cultural History of Smell. Routledge, London, UK.

De Bruxelles, S. (2020). Scents and sensibility! Books' unique smells bottled, Dly Mail, March 30th. Available at: https://www.pressreader.com/uk/daily-mail/20200330/ 282226602823576.

De Hamel, C. (2016). Meetings With Remarkable Manuscripts: Twelve Journeys Into the Medieval World. Penguin, New York, NY, USA.

Delgado, P., Vargas, C., Ackerman, R. and Salmerón, L. (2018). Don’t throw away your printed books: a meta-analysis on the effects of reading media on reading comprehension, Educ. Res. Rev. 25, 23-38. DOI:10.1016/j.edurev.2018.09.003.

Dell'Antonia, K. J. (2011). Why books are better than e-books for children, N. Y. Times, December 28th. Available at: https://parenting.blogs.nytimes.com/2011/12/28/why-booksare-better-than-e-books-for-children/.

Derrida, J. (2005). Paper Machine (trans. R. Bowlby). Stanford University Press, Stanford, CA, USA.

Doucé, L., Poels, K., Janssens, W. and De Backer, C. (2013). Smelling the books: the effect of chocolate scent on purchase-related behavior in a bookstore, J. Environ. Psychol. 36, 65-69. DOI:10.1016/j.jenvp.2013.07.006.

Drobnick, J. (2006). The Smell Culture Reader. Berg, Oxford, UK.

Drobnick, J. (2014). The museum as smellscape, in: Multisensory Museum: Cross-Disciplinary Perspective on Touch, Sound, Smell, Memory and Space, N. Levent and A. Pascual-Leone (Eds), pp. 177-196. Rowman \& Littlefield, Lanham, MD, USA.

Drobnik, J. (2005). Volatile effects: olfactory dimensions of art and architecture, in: Empire of the Senses: the Sensual Culture Reader, D. Howes (Ed.), pp. 265-280. Berg, Oxford, UK.

Duncan, D. and Smyth, A. (2019). Book Parts. Oxford University Press, Oxford, UK.

Eco, U. (1983). The Name of the Rose. Vintage, London, UK.

Edwards, E., Gosden, C. and Phillips, R. B. (2006). Sensible Objects: Colonialism, Museums and Material Culture. Berg, Oxford, UK.

Elliott, S. (2007). Movies soon really will smell; This one, in an ad, like a cake, N. Y. Times, September 3rd. Available at: https://www.nytimes.com/2007/09/03/business/media/ 03scent.html.

Eshelby, K. (2008). The sea, the sea, Time Out (London), May 8-14th, 69.

Fenech, A., Strlič, M., Kralj Cigić, I., Levart, A., Gibson, L. T., de Bruin, G., Ntanos, K., Kolar, J. and Cassar, M. (2010). Volatile aldehydes in libraries and archives, Atmos. Environ. 44, 2067-2073. DOI:10.1016/j.atmosenv.2010.03.021. 
Fenko, A., Schifferstein, H. N. J. and Hekkert, P. (2010). Shifts in sensory dominance between various stages of user-product interactions, Appl. Ergon. 41, 34-40. DOI:10.1016/j.apergo. 2009.03.007.

Flood, A. (2014). Readers absorb less on Kindles than on paper, study finds, Guardian, August 19th. Available at: https://www.theguardian.com/books/2014/aug/19/readers-absorbless-kindles-paper-study-plot-ereader-digitisation.

Fox, M. A. (2005). Market power in music retailing: the case of Wal-Mart, Pop. Mus. Soc. 28, 501-519. DOI:10.1080/03007760500159054.

Gallace, A. and Spence, C. (2014). In Touch With the Future: the Sense of Touch From Cognitive Neuroscience to Virtual Reality. Oxford University Press, Oxford, UK.

Garfield, S. (2011). Just my Type: a Book About Fonts. Profile Books, London, UK.

Gaver, W. W. (1986). Auditory icons: using sound in computer interfaces, Hum.-Comput. Interact. 2, 167-177. DOI:10.1207/s15327051hci0202_3.

González, J., Barros-Loscertales, A., Pulvermüller, F., Meseguer, V., Sanjuán, A., Belloch, V. and Ávila, C. (2006). Reading cinnamon activates olfactory brain regions, Neurolmage 32, 906-912. DOI:10.1016/j.neuroimage.2006.03.037.

Graven, T., Emsley, I., Bird, N. and Griffiths, S. (2020). Improved access to museum collections without vision: how museum visitors with very low or no vision perceive and process tactileauditory pictures, Br. J. Vis. Impair. 38, 79-103. DOI:10.1177/0264619619874833.

Greenwood, V. (2017). Can an archive capture the scents of an entire era? A molecular record of smells could give future generations a sense of the past, Atlantic, May 15th. Available at: https://www.theatlantic.com/science/archive/2017/05/smell-archive/526575/.

Griffiths, F. and Starkey, K. (2018). Sensing through objects, in: Sensory Reflections: Traces of Experience in Medieval Artifacts, F. Griffiths and K. Starkey (Eds), pp. 1-21. Walter de Gruyter, Berlin, Germany. DOI:10.1515/9783110563443-001.

Grothaus, M. (2019). Total recall, in: Reach out and Touch: the Joy of the Physical in the Digital Age, Sappi Europe and J. Brown (Eds), pp. 46-47, 64-65. John Brown, London, UK/Sappi Europe, Brussels, Belgium.

Guest, S., Catmur, C., Lloyd, D. and Spence, C. (2002). Audiotactile interactions in roughness perception, Exp. Brain Res. 146, 161-171. DOI:10.1007/s00221-002-1164-z.

Hagtvedt, H. and Patrick, V. M. (2008). Art infusion: the influence of visual art on the perception and evaluation of consumer products, J. Mark. Res. 45, 379-389. DOI:10.1509/jmkr.45.3. 379.

Halamis, V. and Elbaz, E. (2019). Children's reading comprehension and metacomprehension on screen versus on paper, Comp. Educ. 145, 103737. DOI:10.1016/j.compedu.2019. 103737.

Hamilton, A. (1966). What science is learning about smell, Sci. Digest 55, 81-84.

Handley, L. (2019). Physical books still outsell e-books — and here's why, CNBC News, September 19th. Available at: https://www.cnbc.com/2019/09/19/physical-booksstill-outsell-e-books-and-heres-why.html.

Harris, A. L. (1997). 'Bare things': returning to the senses in Virginia Woolf's The Waves, Literature Interpret. Theory 7, 339-350.

Hartmann, O. and Haupt, S. (2016). Touch! Der Haptic-Effekt im Multisensorischen Marketing, 2nd edn. Haufe Gruppe, Freiburg, Germany.

Haverkamp, M. (2014). Synesthetic Design: Handbook for a Multisensory Approach. Birkhäuser, Basel, Switzerland. 
Heid, M. (2018). Are audiobooks as good for you as reading? Here's what experts say, Time, September 6th. Available at: https://time.com/5388681/audiobooks-reading-books/.

Henshaw, V., McLean, K., Medway, D., Perkins, C. and Warnaby, G. (2018). Designing With Smell: Practices, Techniques and Challenges. Routledge, New York, NY, USA.

Hernandez, D. O. (in press). The weight of paper books. A conversation with Lisa Kuitert, Sens. Soc.

Hertel, R. (2016). The senses in literature: from the modernist shock of sensation to postcolonial and virtual voices, in: A Cultural History of the Senses in the Modern Age, D. Howes (Ed.), pp. 173-194. Bloomsbury Academic, London, UK.

Herz, R. S. and Schooler, J. W. (2002). A naturalistic study of autobiographical memories evoked by olfactory and visual cues: testing the Proustian hypothesis, Am. J. Psychol. 115, 21-32.

Hou, J., Rashid, J. and Lee, K. M. (2017). Cognitive map or medium materiality? Reading on paper and screen, Comp. Hum. Behav. 67, 84-94. DOI:10.1016/j.chb.2016.10.014.

Hunter, D. (1987). Papermaking: History and Technique of an Ancient Craft. Dover Publishing, New York, NY, USA.

Hyndman, S. (2015). The Type Taster: How Fonts Influence You. Type Tasting, London, UK.

Istrati, P. (1928). Les Chardons du Baragan. Bernard Gasset, Paris, France.

Jenner, M. S. R. (2011). Follow your nose? Smell, smelling, and their histories, Am. Hist. Rev. 116, 335-351. DOI:10.1086/ahr.116.2.335.

Jones, B. (2017). 'Smell of data' device sends out an odor when your data is leaking, Digit. Trends, September 1st. Available at: https://www.digitaltrends.com/computing/smell-ofdata-online-security-odor/.

Jones, D. M. (2010; revised 2012). Understanding Place Historic Area Assessments: Principles and Practice. Heritage Publishing, Swindon, UK. [For subsequent versions of this document, see https://historicengland.org.uk/advice/planning/understanding-historic-places/].

Jostmann, N. B., Lakens, D. and Schubert, T. W. (2009). Weight as an embodiment of importance, Psychol. Sci. 20, 1169-1174. DOI:10.1111/j.1467-9280.2009.02426.x.

Kaakinen, J. K., Papp-Zipernovszky, O., Werlen, E., Castells, N., Bergamin, P., Baccino, T. and Jacobs, A. M. (2018). Emotional and motivational aspects of digital reading, in: Learning to Read in a Digital World, M. Barzillai, J. Thomson, S. Schroeder and P. van den Broek (Eds), pp. 141-164. John Benjamins, Amsterdam, The Netherlands. DOI:10.1075/swll.17.06kaa.

Kidd, P. (2020). Coronavirus UK: in tough times, Brucie is getting us through, Times, April 11th. Available at: https://www.thetimes.co.uk/article/coronavirus-uk-in-tough-timesbrucie-is-getting-us-through-2vr7bj8gd.

Kirshenblatt-Gimblett, B. (1999). Playing to the senses: food as a performance medium, Perform. Res. 4, 1-30. DOI:10.1080/13528165.1999.10871639.

Köpper, M., Mayr, S. and Buchner, A. (2016). Reading from computer screen versus reading from paper: does it still make a difference?, Ergonomics 59, 615-632. DOI:10.1080/ 00140139.2015.1100757.

Kuitert, L. (2015). Het Boek en het Badwater. De Betekenis van Papieren Boeken. Amsterdam University Press, Amsterdam, The Netherlands.

Kurby, C. A., Magliano, J. P. and Rapp, D. N. (2009). Those voices in your head: activation of auditory images during reading, Cognition 112, 457-461. DOI:10.1016/j.cognition.2009. 05.007 . 
Laska, M. (2011). The human sense of smell — our noses are much better than we think!, in: Senses and the City: an Interdisciplinary Approach to Urban Sensescapes, M. Diaconu, E. Heuberger, R. Mateus-Berr and L. M. Vosicky (Eds), pp. 145-153. Lit Verlag, Vienna, Austria.

Lattuati-Derieux, A., Bonnassies-Termes, S. and Lavédrine, B. (2006). Characterisation of compounds emitted during natural and artificial ageing of a book. Use of headspace-solid-phase microextraction/gas chromatography/mass spectrometry, J. Cult. Herit. 7, 123-133.

Levent, N. and Pascual-Leone, A. (2014). The Multisensory Museum: Cross-Disciplinary Perspectives on Touch, Sound, Smell, Memory, and Space. Rowman \& Littlefield, Lanham, MD, USA.

Linden, D. J. (2015a). Tactility tactics, Opinion 15.

Linden, D. J. (2015b). Touch: the Science of the Hand, Heart, and Mind. Viking, New York, NY, USA.

Lupton, E. (2007). Skin: Surface, Substance, and Design. Princeton Architectural Press, Hudson, NY, USA.

Lupton, E. (2018). Visualizing sound, in: The Senses: Design Beyond Vision, E. Lupton and A. Lipps (Eds), pp. 204-217. Princeton Architectural Press, Hudson, NY, USA.

Lupton, E. and Lipps, A. (2018). The Senses: Design Beyond Vision. Princeton Architectural Press, Hudson, NY, USA.

Luttinger, N. and Dicum, G. (2006). The Coffee Book: Anatomy of an Industry From Crop to the Last Drop. The New Press, New York, NY, USA.

MacDonald, S. (2007). Exploring the role of touch in connoisseurship and the identification of objects, in: The Power of Touch: Handling Objects in Museums and Heritage Contexts, E. Pye (Ed.), pp. 107-120. Left Coast Press, Walnut Creek, CA, USA.

Mangen, A. and Kuiken, D. (2014). Lost in an iPad: narrative engagement on paper and tablet, Sci. Study Lit 4, 150-177. DOI:10.1075/ssol.4.2.02man.

Mangen, A., Walgermo, B. R. and Brønnick, K. (2013). Reading linear texts on paper versus computer screen: effects on reading comprehension, Int. J. Educ. Res. 58, 61-68. DOI:10. 1016/j.ijer.2012.12.002.

Mangen, A., Olivier, G. and Velay, J.-L. (2019). Comparing comprehension of a long text read in print book and on kindle: where in the text and when in the story?, Front. Psychol. 10, 38. DOI:10.3389/fpsyg.2019.00038.

Margolies, E. (2006). Vagueness gridlocked: a map of the smells of New York, in: The Smell Culture Reader, J. Drobnick (Ed.), pp. 107-117. Berg, Oxford, UK.

Marwood, D. (1971). The Enchanted Island: a Young World Scratch-and-Sniff Book. Young World Productions Limited, London, UK.

McLaughlin, T. (2015). Reading and the Body: the Physical Practice of Reading. Palgrave Macmillan, New York, NY, USA. DOI:10.1007/978-1-137-52289-4.

Moore, A. T. and Schwitzgebel, E. (2018). The experience of reading, Consc. Cogn. 62, 57-68. DOI:10.1016/j.concog.2018.03.011.

Moran, T. (2000a). Ah, the aroma of a just-baked sedan, N. Y. Times, May 14th. Available at: https://www.nytimes.com/2000/05/14/automobiles/ah-the-aroma-of-a-just-bakedsedan.html.

Moran, T. (2000b). Sniffing car parts: yes, the job stinks, N. Y. Times, May 14th. Available at: https://www.nytimes.com/2000/05/14/automobiles/sniffing-car-parts-yes-thejob-stinks.html. 
Moran, T. (2000c). The mysterious human sense of smell: so primitive and so powerful, $N$. Y. Times, May 14th. Available at: https://www.nytimes.com/2000/05/14/automobiles/themysterious-human-sense-of-smell-so-primitive-and-so-powerful.html.

Morrison, G. R. (1986). Communicability of the emotional connotation of type, Educ. Technol. Res. Dev. 34, 235-244. DOI:10.1007/BF02767404.

Mueller, P. A. and Oppenheimer, D. M. (2014). The pen is mightier than the keyboard: advantages of longhand over laptop note taking, Psychol. Sci. 25, 1159-1168. DOI:10.1177/ 0956797614524581.

Neff, J. (2000). Product scents hide absence of true innovation. Advert. Age, February 21st. Available at: https://adage.com/article/news/product-scents-hide-absence-trueinnovation/59353.

O'Connor, F. (1969). The nature and aim of fiction, in: Mystery and Manners: Occasional Prose, S. Fitzgerald and R. Fitzgerald (Eds), pp. 63-86. Farrar Strauss and Giroux, New York, NY, USA.

Oram, R. W. and Bishop, E. L. (2005). The sweet smell of provenance, Chron. High. Educ. 52, B18-B19.

Parish-Morris, J., Mahajan, N., Hirsh-Pasek, K., Golinkoff, R. M. and Collins, M. F. (2013). Once upon a time: parent-child dialogue and storybook reading in the electronic era, Mind Brain Educ. 7, 200-211. DOI:10.1111/mbe.12028.

Parisi, D. (2018). Archaeologies of Touch: Interfacing With Haptics From Electricity to Computing. University of Minnesota Press, Minneapolis, MN, USA.

Patel, B. (2020). Chocolat author Joanne Harris claims fewer women win literary prizes because the 'pink and frivolous' covers publishers assign to their books mean they're not taken seriously. Dly Mail Online, February 13th. Available at: https://www.dailymail.co.uk/femail/article-7999759/Author-Joanne-Harris-says-fewerwomen-win-literary-prizes-pink-frivolous-covers.html.

Perrone-Bertolotti, M., Kujala, J., Vidal, J. R., Hamame, C. M., Ossandon, T., Bertrand, O., Minotti, L., Kahane, P., Jerbi, K. and Lachaux, J.-P. (2012). How silent is silent reading? Intracerebral evidence for top-down activation of temporal voice areas during reading, J. Neurosci. 32, 17554-17762. DOI:10.1523/JNEUROSCI.2982-12.2012.

Preston, A. (2017). How real books have trumped ebooks, Guardian, May 14th. Available at: https://www.theguardian.com/books/2017/may/14/how-real-books-trumpedebooks-publishing-revival.

Pye, E. (2007). The Power of Touch: Handling Objects in Museums and Heritage Contexts. Left Coast Press, Walnut Creek, CA, USA.

'Register' (2020). Vaughan Oliver: album cover designer responsible for capturing the spirit of dark and complex alt-rock bands such as the Cocteau Twins, Times, March 10th. Available at: https://www.thetimes.co.uk/article/vaughan-oliver-obituary-qmtzhfxf5.

Reinarz, J. (2014). Past Scents: Historical Perspectives on Smell. University of Illinois Press, Champaign, IL, USA.

Rindisbacher, H. J. (1992). The Smell of Books: a Cultural-Historical Study of Olfactory Perception in Literature. University of Michigan Press, Ann Arbor, MI, USA.

Rogowsky, B. A., Calhoun, B. M. and Tallal, P. (2016). Does modality matter? The effects of reading, listening, and dual modality on comprehension, SAGE Open 6. DOI:10.1177/ 2158244016669550 . 
Roseberry, S., Hirsh-Pasek, K., Parish-Morris, J. and Golinkoff, R. M. (2009). Live action: can young children learn verbs from video?, Child Dev. 80, 1360-1375. DOI:10.1111/j.14678624.2009.01338.x.

Ruecker, S. (2002). Carrying the pleasure of books into the design of the electronic book, in: Pleasure With Products: Beyond Usability, W. S. Green and P. W. Jordan (Eds), pp. 130-140. Taylor and Francis, London, UK.

Ruecker, S. (2006). The sensual pleasure of books, Sens. Soc. 1, 109-111. DOI:10.2752/ 174589206778055646.

Sappi Europe and Brown, J. (2019). Reach out and Touch: the Joy of the Physical in the Digital Age. John Brown, London, UK/Sappi Europe, Brussels, Belgium.

Sax, D. (2019). Let's get physical, in: Reach out and Touch: The Joy of the Physical in the Digital Age, Sappi Europe and J. Brown (Eds), pp. 30-35, 64-65. John Brown, London, UK/Sappi Europe, Brussels, Belgium.

Send, A. (2018). Birds in hand: micro-books and the devotional experience, in: Sensory Reflections: Traces of Experience in Medieval Artifacts, F. Griffiths and K. Starkey (Eds), pp. 181-202. Walter de Gruyter, Berlin, Germany. DOI:10.1515/9783110563443-001.

Sheldon, R. and Arens, E. (1932). Consumer Engineering: a New Technique for Prosperity. Harper and Brothers Publishers, New York, NY, USA.

Singer, L. M. and Alexander, P. A. (2017). Reading on paper and digitally: what the past decades of empirical research reveal, Rev. Educ. Res. 87, 1007-1041. DOI:10.3102/ 0034654317722961.

Skedung, L., Arvidsson, M., Chung, J. Y., Stafford, C. M., Berglund, B. and Rutland, M. W. (2013). Feeling small: exploring the tactile perception limits, Sci. Rep. 3, 2617. DOI:10. 1038/srep02617.

Smith, M. M. (2007). Producing sense, consuming sense, making sense: perils and prospects for sensory history, J. Soc. Hist. 40, 841-858.

Smith, M. M. (2015). The Smell of Battle, the Taste of Siege a Sensory History of the Civil War. Oxford University Press, Oxford, UK.

Spence, C. (2002). The ICI Report on the Secret of the Senses. The Communication Group, London, UK.

Spence, C. (2019a). Icons of touch, in Reach out and Touch: the Joy of the Physical in the Digital Age, Sappi Europe and J. Brown (Eds), pp. 14-15, 64-65. John Brown, London, UK/Sappi Europe, Brussels, Belgium.

Spence, C. (2019b). Tactile/haptic aspects of multisensory packaging design, in: Multisensory Packaging: Designing New Product Experiences, C. Velasco and C. Spence (Eds), pp. 127159. Palgrave Macmillan, Cham, Switzerland. DOI:10.1007/978-3-319-94977-2_6.

Spence, C. and Gallace, A. (2011). Multisensory design: reaching out to touch the consumer, Psychol. Mark. 28, 267-308. DOI:10.1002/mar.20392.

Spence, C. and Piqueras-Fiszman, B. (2011). Multisensory design: weight and multisensory product perception, in: Proceedings of RightWeight2, G. Hollington (Ed.), pp. 8-18. Materials KTN, London, UK.

Stanton, T. R. and Spence, C. (2020). The influence of auditory cues on bodily and movement perception, Front. Psychol. 10, 3001. DOI:10.3389/fpsyg.2019.03001. 
Stiles, K. (1998). Uncorrupted joy: international art actions, in: Out of Actions: Between Performance and the Object, 1949-1979, P. Schimmel and K. Stiles (Eds), pp. 227-329. Museum of Contemporary Art, Los Angeles, CA, USA/Thames and Hudson, New York, NY, USA.

Stoltzfus, K. (2016). Do 'digital natives' prefer paper books to e-books? Educ. Week, November 8th. Available at: http://www.edweek.org/ew/articles/2016/11/09/do-digital-natives-preferpaper-books-to.html.

Strlič, M. and Kolar, J. (2008). Recent developments in non- and micro-destructive analysis of historical paper, in: New Trends in Analytical, Environmental and Cultural Heritage Chemistry, M. P. Colombini and L. Tassi (Eds), pp. 477-491. Transworld Research Network, Kerala, India.

Strlič, M., Thomas, J., Trafela, T., Cséfalvayová, L., Kralj Cigić, I., Kolar, J. and Cassar, M. (2009). Material degradomics: on the smell of old books, Anal. Chem. 81, 8617-8622. DOI:10.1021/ac9016049.

Tanizaki, J. (2001). In Praise of Shadows. Vintage Publishing, London, UK.

Tedeschi, B. (2011). For the iPad, books that respond to a child's touch. N. Y. Times, June 29th. Available at: https://www.nytimes.com/2011/06/30/technology/personaltech/30smart.html.

Thomson, I. (2016). Meeting with remarkable manuscripts — review. Guardian, September 25th. Available at: https://www.theguardian.com/books/2016/sep/25/meetings-remarkablemanuscripts-christopher-hamel-illuminated.

Troseth, G. L., Strouse, G. A., Flores, I., Stuckelman, Z. D. and Johnson, C. R. (2020). An enhanced eBook facilitates parent-child talk during shared reading by families of low socioeconomic status, Early Child, Res. Q. 50, 45-58. DOI:10.1016/j.ecresq.2019.02.009.

Uzanne, O. (1895). La fin des livres, in: Contes Pour les Bibliophiles, O. Uzanne and A. Robida (Eds), pp. 125-145. Quantin, Paris, France.

Van Campen, C. (2014). The Proust Effect: the Senses as Doorways to Lost Memories. Oxford University Press, Oxford, UK.

van Egmond, R. (2004). Compact disc cover design: transfer of musical style and emotional contents into graphical design, in: Design and Emotion: the Experience of Everyday Things, D. McDonagh, P. Hekkert, J. van Erp and D. Gyi (Eds), pp. 238-242. Taylor and Francis, London, UK.

Van Lente, R. and Herman, S. J. (2001). The smell of success - exploiting the leather aroma, in: Human Factors in Automative Design (SP-1591). SAE Technical Paper 2001-01-0047. Proceedings of SAE 2001 World Congress, Detroit, MI, USA. DOI:10.4271/2001-01-0047.

van Rompay, T. J. L. and Pruyn, A. T. H. (2011). When visual product features speak the same language: effects of shape-typeface congruence on brand perception and price expectations, J. Prod. Innov. Manage. 28, 599-610. DOI:10.1111/j.1540-5885.2011.00828.x.

Velasco, C. and Spence, C. (2019). The role of typeface in packaging design, in: Multisensory Packaging: Designing New Product Experiences, C. Velasco and C. Spence (Eds), pp. 79101. Palgrave Macmillan, Cham, Switzerland. DOI:10.1007/978-3-319-94977-2_4.

Venkatesan, T., Wang, Q. J. and Spence, C. (in press). Does the typeface on album cover influence expectations and perception of music? Psychol. Aesthet. Creat. Arts.

Vinge, L. (1975). The Five Senses: Studies in a Literary Tradition. LiberLäromedel, Lund, Denmark.

Walsh, G. (2016). Screen and paper reading research - a literature review, Aust. Acad. Res. Libraries 47, 160-173. DOI:10.1080/00048623.2016.1227661. 
Whitelocks, S. (2012). Weirdest perfume ever? Scent company create 'Eau de MacBook Pro' for art project. Dly Mail Online, April 20th. Available at: http://www.dailymail.co.uk/femail/article-2132702/Apple-Mac-Weirdest-perfume-Scentcompany-create-Eau-MacBook-Pro-art-project.html?ito=feeds-newsxml.

Wight, E. and Dowell, B. (2020). Nazi photo album made from HUMAN SKIN of a death camp victim is discovered after collector noticed book cover had 'a tattoo, human hair and bad smell'. Dly Mail Online, March 5th. Available at: https://www.dailymail.co.uk/news/article8077785/Nazi-photo-album-HUMAN-SKIN-death-camp-victim-discovered.html.

Winkielman, P., Schwarz, N., Fazendeiro, T. A. and Reber, R. (2003). The hedonic marking of processing fluency: implications for evaluative judgment, in: The Psychology of Evaluation: Affective Processes in Cognition and Emotion, J. Musch and K. C. Klauer (Eds), pp. 189217. Erlbaum, Mahwah, NJ, USA.

Winton, T. (2008). Breath. Picador, London, UK.

Wolf, M. (2018). Reader, Come Home: the Reading Brain in a Digital World. HarperCollins, New York, NY, USA.

Woody, W. D., Daniel, D. B. and Baker, C. A. (2010). E-books or textbooks: students prefer textbooks, Comp. Educ. 55, 945-948. DOI:10.1016/j.compedu.2010.04.005. 